\title{
Transgenic Expression of Replication-restricted Enteroviral Genomes in Heart Muscle Induces Defective Excitation-Contraction Coupling and Dilated Cardiomyopathy
}

\author{
Rainer Wessely, ${ }^{\star}$ Karin Klingel, ${ }^{\ddagger}$ L.F. Santana, ${ }^{\S}$ Nancy Dalton, ${ }^{\star}$ Minoru Hongo, ${ }^{\text {W }}$. Jonathan Lederer, ${ }^{\S}$ Reinhard Kandolf, ${ }^{\ddagger}$ \\ and Kirk U. Knowlton* \\ *Department of Medicine, University of California, San Diego, School of Medicine, La Jolla, California 92093-0613; ${ }^{*}$ Department of \\ Molecular Pathology, Institute for Pathology, University of Tübingen, D-72070, Tübingen, Germany; and ${ }^{\S}$ Departments of Molecular \\ Biology and Biophysics and Physiology, Medical Biotechnology Center and School of Medicine, University of Maryland, Baltimore, \\ Maryland 21201
}

\begin{abstract}
Numerous studies have implicated Coxsackievirus in acute and chronic heart failure. Although enteroviral nucleic acids have been detected in selected patients with dilated cardiomyopathy, the significance of such persistent nucleic acids is unknown. To investigate the mechanisms by which restricted viral replication with low level expression of Coxsackieviral proteins may be able to induce cardiomyopathy, we generated transgenic mice which express a replication-restricted full-length Coxsackievirus B3 (CVB3) cDNA mutant $(\mathrm{CVB} 3 \Delta \mathrm{VP} 0)$ in the heart driven by the cardiac myocyte-specific myosin light chain-2v (MLC-2v) promoter. CVB3 $\triangle$ VP0 was generated by mutating infectious CVB3 cDNA at the VP4/VP2 autocatalytic cleavage site from AsnSer to Lys-Ala. Cardiac-specific expression of this cDNA leads to synthesis of positive- and negative-strand viral RNA in the heart without formation of infectious viral progeny. Histopathologic analysis of transgenic hearts revealed typical morphologic features of myocardial interstitial fibrosis and in some cases degeneration of myocytes, thus resembling dilated cardiomyopathy in humans. There was also an increase in ventricular atrial natriuretic factor mRNA levels, demonstrating activation of the embryonic program of gene expression typical of ventricular hypertrophy and failure. Echocardiographic analysis demonstrated the presence of left ventricular dilation and decreased systolic function in the transgenic mice compared with wild-type littermates, evidenced by increased ventricular end-diastolic and end-systolic dimensions and decreased fractional shortening. Analysis of isolated myocytes from transgenic mice demonstrate that there is defective excitation-contraction coupling and a decrease in the magnitude of isolated cell shortening. These data demonstrate that restricted replication of enteroviral genomes in the heart can induce dilated
\end{abstract}

Address correspondence to Kirk U. Knowlton, M.D., Department of Medicine, 0613c, University of California, San Diego, 9500 Gilman Dr., La Jolla, CA 92093-0613c. Phone: 619-822-1363; FAX: 619-8221365; E-mail: kknowlton@ucsd.edu Rainer Wessely's current address is Cardiology Division, German Heart Center, Clinic at the Technical University, Munich, Germany.

Received for publication 9 October 1997 and accepted in revised form 4 August 1998.

J. Clin. Invest.

(C) The American Society for Clinical Investigation, Inc. 0021-9738/98/10/1444/10 \$2.00

Volume 102, Number 7, October 1998, 1444-1453

http://www.jci.org cardiomyopathy with excitation-contraction coupling abnormalities similar to pressure overload models of dilated cardiomyopathy. (J. Clin. Invest. 1998. 102:1444-1453.) Key words: picornavirus • enterovirus • myocarditis • heart failure $\cdot$ calcium

\section{Introduction}

Enteroviruses, including Coxsackievirus B (CVB), ${ }^{1}$ are known to induce viral myocarditis. Acute viral replication may cause rapid and severe cardiac dysfunction. The patient may experience full recovery or a progressive disease that ultimately leads to dilated cardiomyopathy. Dilated cardiomyopathy is characterized by enlargement of the heart chambers, impaired myocardial and ventricular function, and heart failure (for reviews see references 1 and 2). Heart failure due to dilated cardiomyopathy is the indication for cardiac transplantation in $\sim 45 \%$ of patients in the United States, a percentage similar to that of patients with coronary artery disease undergoing transplantation (3). The cause of dilated cardiomyopathy is unknown in most cases. Persistent enteroviral genomes have been identified by PCR and in situ hybridization in the hearts of a subset of patients with dilated cardiomyopathy $(1,4)$, and this finding has led to the suggestion that enteroviruses may play a role in the pathogenesis of this disorder. However, it is controversial whether the presence of enteroviral genomes in the heart is etiologically significant in chronic disease, or whether they represent remnants of a previous infection. Notably, infectious virus progeny and viral protein usually cannot be detected in patients with dilated cardiomyopathy by conventional means such as virus isolation or immunohistochemistry.

Coxsackievirus is a member of the picornavirus family and the enterovirus genus. Several picornaviruses including CVB3 have been shown to establish persistent infections in vivo and in vitro in several diseases and cell types (5-14). Persistent Coxsackieviral infection in the murine heart is qualitatively distinct from acute viral infection. Distinguishing characteristics of persistent viral infection from those of acute infection include a decrease in the total amount of viral RNA, a decrease in the ratio of positive- to negative-strand viral RNA, low levels of viral protein expression reflecting restricted virus replication, and inability to isolate infectious virus from in vivo tissue samples during chronic disease (5). The decreased ratio of positive- to negative-strand RNA indicates that the persistence of enteroviral genomes in the heart is due to inhibition of

1. Abbreviations used in this paper: ANF, atrial natriuretic factor; CVB, Coxsackievirus B; EC, excitation-contraction; MLC, myosin light chain. 
viral positive-strand genomic RNA synthesis. Positive-strand enteroviral RNA is replicated through a negative-strand RNA intermediate that requires expression of the viral RNA-dependent RNA polymerase. The final maturation step for formation of infectious virus progeny requires autocatalytic cleavage of the capsid protein VP0 to VP4 and VP2. To study the effect of restricted viral replication in cardiac myocytes, we generated a plasmid-based expression vector that directs expression of a mutated copy of the full-length CVB3 genome, without formation of lytic infectious virus particles. This was accomplished by mutating the autocatalytic cleavage site of VP0 in an infectious cDNA copy of CVB3, thereby preventing the final maturation cleavage of the viral capsid. In previous experiments it has been shown that expression of this mutant CVB3 genome is able to induce a cytopathic effect in cardiac myocytes that is independent of a host cellular immune response and that this effect is associated with a pattern of RNA expression consistent with restricted viral replication (15).

To understand whether persistent expression in the intact heart of enteroviral genomes (having a restricted pattern of viral replication) is sufficient to induce dilated cardiomyopathy, we generated transgenic mice with cardiac-specific expression of the mutant full-length copy of the CVB3 genome using the myosin light chain (MLC)-2v promoter (16). Here, we show that transgenic mice expressing CVB3 genomes have abnormal excitation-contraction (EC) coupling similar to that observed in a pressure overload model of cardiomyopathy (17), and develop dilated cardiomyopathy with molecular, histologic, and functional features resembling human disease.

\section{Methods}

Construction of the transgene and generation of transgenic mice. A noninfectious cDNA copy of the CVB3 genome was generated as reported previously (15) by site-directed mutagenesis of pCB3-M1, the infectious cDNA copy of the CVB3 genome $(18,19)$. In brief, nucleotides 942 (C) and 943 (T) were both changed to G, thus altering the amino acids of the VP0 cleavage site from Asn-Ser to Lys-Ala (15). The mutated construct is referred as CVB3 $\triangle \mathrm{VP} 0$. The viral mutations were confirmed by dideoxynucleotide sequencing (20).

pMLC-2v CVB3 $\triangle V P 0$, the plasmid used for the transgenic construct, was generated by inserting the CVB3 $\triangle \mathrm{VP} 0$ cDNA downstream from the 250-bp cardiac-specific promoter MLC-2v using the pMLC-SV0A expression plasmid (21). pMLC-SV0A contains polyadenylation signals upstream of the MLC-2v promoter to prevent read-through transcription from cryptic promoters. It also contains the luciferase polyadenylation signal downstream from the multiple cloning site. The pMLC-SV0A vector was modified by adding the octameric restriction sites PacI and AscI at HindIII and KpnI sites of the original vector. CVB3 $\Delta V P 0$ was excised from $p C M V$ CVB3 $\Delta V P 0$ (15) as an SpeI-NotI fragment and subcloned into pMLC-SV0A yielding pMLC-2v CVB3 $\Delta$ VP0 (see Fig. 1).

The male pronuclei of fertilized eggs from superovulated C57BL $/ 6 \times$ Balb/c mice were injected with 1-2 pl of DNA at a concentration of $1 \mathrm{ng} / \mu \mathrm{l}$. Injected eggs were transferred into the oviduct of pseudopregnant CD1 mice. At 4 wk of age potential founder mice were sexed, ear punched, and distal tail excised for DNA analysis. Founder mice were bred with Balb/c mice and maintained in a pathogen-free environment.

Plaque-forming assay. Mouse hearts were homogenized, resuspended in $1 \mathrm{ml} \mathrm{DME} /$ medium 199 4:1 medium containing 2\% heatinactivated FBS, and were subjected three times to a freeze/thaw cycle to release infectious virus. After centrifugation at $3,000 \mathrm{~g}$ the supernatant was subjected to several 1:10 dilutions and incubated on HeLa cell monolayers in 6-well plates (Nunc, Inc., Naperville, IL) for 60 min. Thereafter, the monolayer was overlaid with a $37^{\circ} \mathrm{C} 1: 1$ mixture of agar (final concentration 0.65\%; DIFCO, Detroit, MI) in PBS and DME including penicillin $(200 \mathrm{U} / \mathrm{ml})$ and streptomycin $(200 \mu \mathrm{g} / \mathrm{ml})$, $2 \%$ glutamine, and $4 \%$ heat-inactivated FBS. The plates were incubated at $37^{\circ} \mathrm{C}$ and $5 \% \mathrm{CO}_{2}$ for $48 \mathrm{~h}$. Then the cells were fixed with an acetic acid/methanol solution (1:3) and the cell layers were stained with a $1 \%$ crystal violet solution.

$R T-P C R$. RNA was isolated from ventricles of mouse hearts using Tripure Isolation reagent (Boehringer Mannheim, Arlington Heights, IL) according to the protocol provided by the manufacturer and treated with DNase I (Life Technologies, Inc., Gaithersburg, MD) for $15 \mathrm{~min}$ at room temperature to digest remaining DNA. DNase I was inactivated by adding $10 \mathrm{mM}$ EDTA and heating to $65^{\circ} \mathrm{C}$ for $10 \mathrm{~min}$. Primers were designed corresponding to the $5^{\prime}$ untranslated region of the Coxsackieviral RNA as described previously (15). The sequences of the primers were: CP1: 5'-ACCTTTGTGCGCCTGTT-3'; CP2: 5' -CACGGACACCCAAAGTA-3'. RT-PCR was performed as follows. $2 \mu \mathrm{g}$ of RNA was used for reverse transcription. The appropriate primer (CP1 or CP2) was allowed to anneal for $10 \mathrm{~min}$ at $70^{\circ} \mathrm{C}$. Reverse transcription was then carried out at $42^{\circ} \mathrm{C}$ for 50 min using $1 \mu \mathrm{l}$ of Superscript II reverse transcriptase (200 U/ $/$ l; Life Technologies, Inc.) in buffer containing $20 \mathrm{mM}$ Tris$\mathrm{HCl}(\mathrm{pH} 8.4), 50 \mathrm{mM} \mathrm{KCl}, 1 \mathrm{mM}$ DTT, and $2.5 \mathrm{mM} \mathrm{MgCl}_{2}$. The reaction was terminated by heating to $70^{\circ} \mathrm{C}$ for $10 \mathrm{~min}$ and digesting the remaining RNA with Escherichia coli RNase H (Life Technologies, Inc.). For amplification of positive-strand RNA the $\mathrm{CP} 2$ primer was used for reverse transcription. Negative-strand RNA was amplified by hybridizing the $\mathrm{CP} 1$ primer for reverse transcription. The samples were then amplified with $\mathrm{CP} 1$ and $\mathrm{CP} 2$ primers at $94^{\circ} \mathrm{C}(1 \mathrm{~min}), 52^{\circ} \mathrm{C}$ $(1 \mathrm{~min})$, and $72^{\circ} \mathrm{C}(2 \mathrm{~min})$ for a total of 36 cycles using VENT-DNApolymerase in a total volume of $100 \mu \mathrm{l}$. Appropriate controls were used for every step to control for sensitivity and specificity of the amplification. $10-\mu l$ aliquots of samples were then analyzed on an $1 \%$ agarose gel containing $10 \mu \mathrm{g} / \mathrm{ml}$ ethidium bromide.

In situ hybridization. Single-stranded ${ }^{35}$ S-labeled RNA probes for strand-specific in situ detection of viral positive- or negative-strand RNA were synthesized from the dual-promoter plasmid pCVB3-R1 by using either T7 or SP6 RNA polymerase (22). Control RNA probes were synthesized from nonrecombinant transcription vector pSPT18.

Myocardial tissue was fixed for $24 \mathrm{~h}$ in phosphate-buffered $4 \%$ paraformaldehyde and embedded in paraffin. Pretreatment, hybridization, and washing conditions were as described previously (5). In brief, dewaxed tissue sections were hybridized at $42^{\circ} \mathrm{C}$ for $18 \mathrm{~h}$ in a hybridization mixture containing ${ }^{35} \mathrm{~S}$-labeled strand-specific CVB3 cRNA probes $(500 \mathrm{ng} / \mathrm{ml}), 10 \mathrm{mM}$ Tris- $\mathrm{HCl}(\mathrm{pH} 7.4), 50 \%$ (vol/vol) deionized formamide, $600 \mathrm{mM} \mathrm{NaCl}, 1 \mathrm{mM}$ EDTA, $0.02 \%$ polyvinylpyrrolidone, $0.02 \%$ Ficoll, $0.05 \%$ BSA, $10 \%$ (wt/vol) dextran sulfate, $10 \mathrm{mM}$ dithiothreitol, sonicated denatured salmon sperm DNA $(200 \mu \mathrm{g} / \mathrm{ml})$, and rabbit liver tRNA $(100 \mu \mathrm{g} / \mathrm{ml})$. Slides were washed for $30 \mathrm{~min}$ at $42^{\circ} \mathrm{C}$ in $2 \times \mathrm{SSC} / 50 \%$ formamide. Nonhybridized singlestranded RNA probes were digested by RNase A $(20 \mu \mathrm{g} / \mathrm{ml})$ in 10 $\mathrm{mM}$ Tris- $\mathrm{HCl}, \mathrm{pH} 8.0,0.5 \mathrm{M} \mathrm{NaCl}$ for $30 \mathrm{~min}$ at $37^{\circ} \mathrm{C}$. Slides were washed again for $30 \mathrm{~min}$ at $50^{\circ} \mathrm{C}$ in $2 \times \mathrm{SSC} / 50 \%$ formamide and for $1 \mathrm{~h}$ at $55^{\circ} \mathrm{C}$ in $2 \times \mathrm{SSC}$, then dehydrated in graded ethanol solutions containing $300 \mathrm{mM}$ ammonium acetate. Hybridized slide preparations were autoradiographed with NTB2 nuclear track emulsion (Kodak, Rochester, NY). After autoradiographic exposure for $3 \mathrm{wk}$ at $4^{\circ} \mathrm{C}$, slides were developed with Kodak D19, counterstained with hematoxylin and eosin, and examined under a Zeiss microscope.

TUNEL stain. Ventricles from transgenic and nontransgenic littermates were fixed in $1 \%$ paraformaldehyde in PBS overnight at $4^{\circ} \mathrm{C}$. They were then placed in $30 \%$ sucrose in PBS at $4^{\circ} \mathrm{C}$ until saturated. The samples were then frozen in liquid nitrogen using OCT and stored at $-70^{\circ} \mathrm{C}$. 5- $\mu \mathrm{m}$ sections were then stained using Apop-Tag detection kit (Oncor Inc., Gaithersburg, MD) except that the sections were permeabilized for 2 min at $4^{\circ} \mathrm{C}$ with $0.1 \%$ Triton $\mathrm{X}-100$ and $0.1 \%$ sodium citrate. As a positive control cells were treated with 0.04 


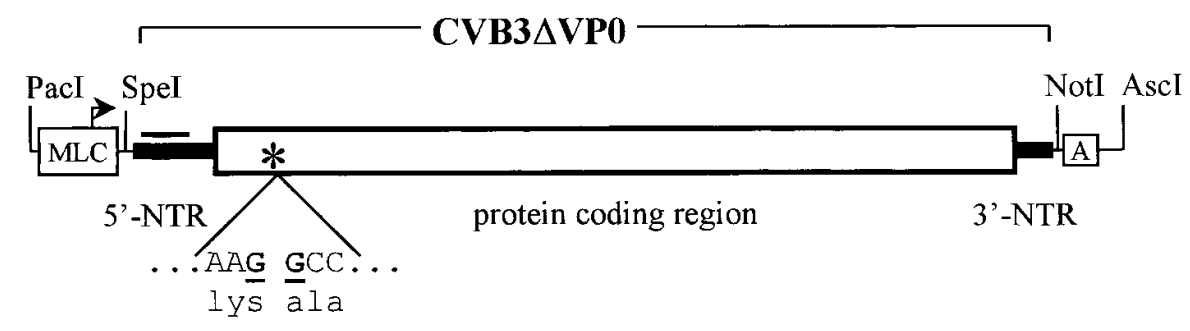

Figure 1. MLC-2v CVB3 3 VP0 transgene. A replication-restricted cDNA copy of the CVB3 genome was generated by mutating the VP0 autocatalytic cleavage site $(*)$ in the wild-type, full-length infectious cDNA copy of the CVB3 genome $(18,21)$. The Asn-Ser cleavage site was changed to LysAla by site-directed mutagenesis of the AAC-TCC codons to AAG-GCC. The full-length CVB3 $\Delta \mathrm{VP} 0$ including the $5^{\prime}$ nontranslated region $\left(5^{\prime}-N T R\right)$, the protein coding region, and the $3^{\prime}$ nontranslated region $\left(3^{\prime}-N T R\right)$ was inserted downstream from the cardiacspecific 250-bp MLC-2v (MLC) promoter (nucleotides -250 to +12 from the transcriptional start site, arrow) at SpeI and NotI restriction enzyme sites. The bar above the 5'-NTR represents the PCR fragment amplified (nucleotides 67-562) to screen transgenic mice for presence of transgene, and to detect expression of viral RNA using RT-PCR with the primers CP1 and CP2 described in Methods. The 8.0-kb transgene, MLC-2v CVB3 $\Delta$ VP0, was excised for oocyte microinjection by digesting with PacI and AscI.

U/ $\mu$ l DNase I (Sigma Chemical Co., St. Louis, MO), and as a negative control terminal deoxynucleotidyl transferase was omitted from the protocol. The nuclei of the cells were also stained with bisbenzimide Hoechst dye No. 33258 (Sigma; $1 \mu \mathrm{g} / \mathrm{ml}$ ), for $2 \mathrm{~min}$ at room temperature. The number of apoptotic nuclei per cross-sectional slice of the mid-ventricular wall was determined.

Echocardiography. M-mode echocardiograms were performed as described previously (23). In brief, animals were anesthetized using $100 \mathrm{mg} / \mathrm{kg}$ ketamine and $5 \mathrm{mg} / \mathrm{kg}$ xylazine, intraperitoneally. The anterior chest was shaved and small needle ECG leads were placed through the skin on the right and left lower extremities and the right upper extremity with the animal in the left lateral decubitus position.

The echocardiographic and Doppler studies were performed on an Apogee CX (ATL Interspec, Bothell, WA) system that was equipped with a 9-MHz dynamically focused symmetrical annular array transducer.

Isolated cell contractile function and EC coupling. Single ventricular myocytes were isolated from transgenic and nontransgenic littermates using a previously described procedure $(17,24)$. Membrane currents were measured using whole-cell configuration of the patchclamp technique with an Axopatch-200A amplifier (Axon Instruments, Foster City, CA). During the experiments cells were continuously superfused with a normal Tyrode's solution $(140 \mathrm{mM} \mathrm{NaCl}, 0.5$ $\mathrm{mM} \mathrm{MgCl} 2,0.33 \mathrm{mM} \mathrm{NaH} \mathrm{PO}_{4}, 5 \mathrm{mM}$ Hepes, $5.5 \mathrm{mM}$ glucose, 1.8 $\mathrm{mM} \mathrm{CaCl}_{2}$, and $5 \mathrm{mM} \mathrm{KCl}$; $\mathrm{pH} \mathrm{7.4)} \mathrm{at} \mathrm{a} \mathrm{temperature} \mathrm{of} 34-37^{\circ} \mathrm{C}$. After establishing the whole-cell patch-clamp, the external solution was changed to a modified normal Tyrode's solution designed to block $\mathrm{K}^{+}$currents and isolate $\mathrm{I}_{\mathrm{Ca}}$ by substituting (1:1) $\mathrm{CsCl}$ for $\mathrm{KCl}$. Measurements of membrane currents were then obtained, and $\left[\mathrm{Ca}^{2+}\right]_{\mathrm{i}}$ was measured along with $\mathrm{Ca}^{2+}$ sparks while carrying out whole-cell clamp measurements using an MRC600 confocal microscope $(17,25)$.

Statistical analysis. Data are shown as mean \pm SE. Multiple comparisons were evaluated using single factor ANOVA and post-hoc $t$ test with Bonferroni correction.

\section{Results}

Generation of transgenic mice. A replication-restricted, fulllength mutant cDNA copy of the CVB3 genome (CVB3$\Delta \mathrm{VP0}$ ) (15) was inserted downstream from a 250-bp cardiac-specific MLC-2v promoter (pMLC-2v CVB3 $3 \mathrm{VP} 0$ ) as described in Methods (Fig. 1). Transfection of the pMLC-2v CVB3 $\Delta$ VP0 plasmid expression vector into cultured neonatal rat ventricular myocytes results in synthesis of both positiveand negative-strand viral RNA using strand-specific nested RT-PCR (data not shown), confirming that pMLC-2v CVB3$\triangle \mathrm{VP0}$ was able to direct expression of CVB3 genome in cardiac myocytes in a replication-restricted manner.

The 8.0-kb MLC-2v CVB3 $\Delta$ VP0 expression cassette was isolated after cleavage with AscI and PacI, and microinjected into C57BL $/ 6 \times \mathrm{Balb} / \mathrm{c}$ mouse oocytes as described previously (26). Transgene-positive founder mice were bred with Balb/c mice. Genotypes of mice were confirmed using Southern (DNA) blot analysis and PCR from tail DNA. Of 82 founder generation pups, the transgene integrated into the genome of 21 pups as determined by PCR with genomic tail DNA using transgene-specific primers that hybridized to the $5^{\prime}$ end of the viral cDNA. Southern blotting using a probe for viral DNA confirmed the presence of the transgene in PCR-positive mice (data not shown).

Strand-specific detection of viral transgene expression. Of the 21 positive founder mice, heterozygous mice of the $\mathrm{F}_{1}-\mathrm{F}_{3}$ generation from three lines $(36,49$, and 53$)$ that successfully transmitted the transgene to their progeny and had elevated levels of atrial natriuretic factor (ANF) mRNA in the ventricle were further analyzed. RT-PCR of RNA from the ventricles of transgenic mice confirmed the presence of both positive- and negative-strand viral RNA, interestingly, with a larger amount of negative- than positive-strand viral RNA (Fig. 2). The efficiency of reverse transcription using the $\mathrm{CP} 1$ and $\mathrm{CP} 2$ primers was shown previously to be comparable by amplifying viral RNA from myocytes infected with wild-type CVB3 (15). As

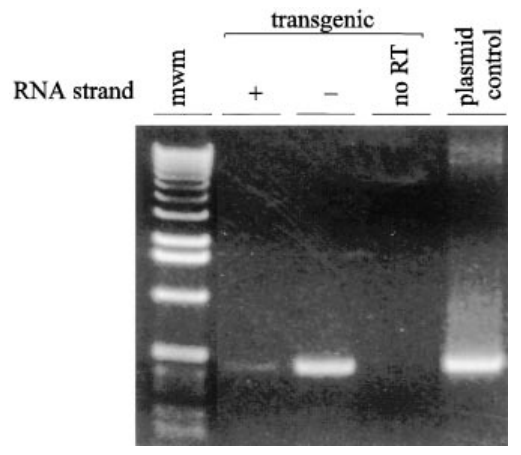

Figure 2. Detection of both positive- and negative-strand viral RNA in the ventricle. RTPCR on RNA from the ventricle of a transgenic mouse was performed, using primers that anneal to the $5^{\prime}$ nontranslated region of the CVB3 genome, and amplified a 495-bp fragment from nucleotides $67-562$. Both positiveand negative-strand RNA were detected in the ventricles of the transgenic heart with more DNA amplified from the negative- than the positive-strand RNA. Notably, the faint amplification of positivestrand viral genomic RNA was a consistent finding in transgenic hearts. To rule out contamination with genomic DNA that may not have been digested by DNase I, samples were also amplified in identical manner except that reverse transcriptase was omitted (no RT). It has been demonstrated previously that the $\mathrm{CP} 1$ and $\mathrm{CP} 2$ primers used for reverse transcription are able to amplify positive- and negative-strand RNA with similar efficiency (15). 


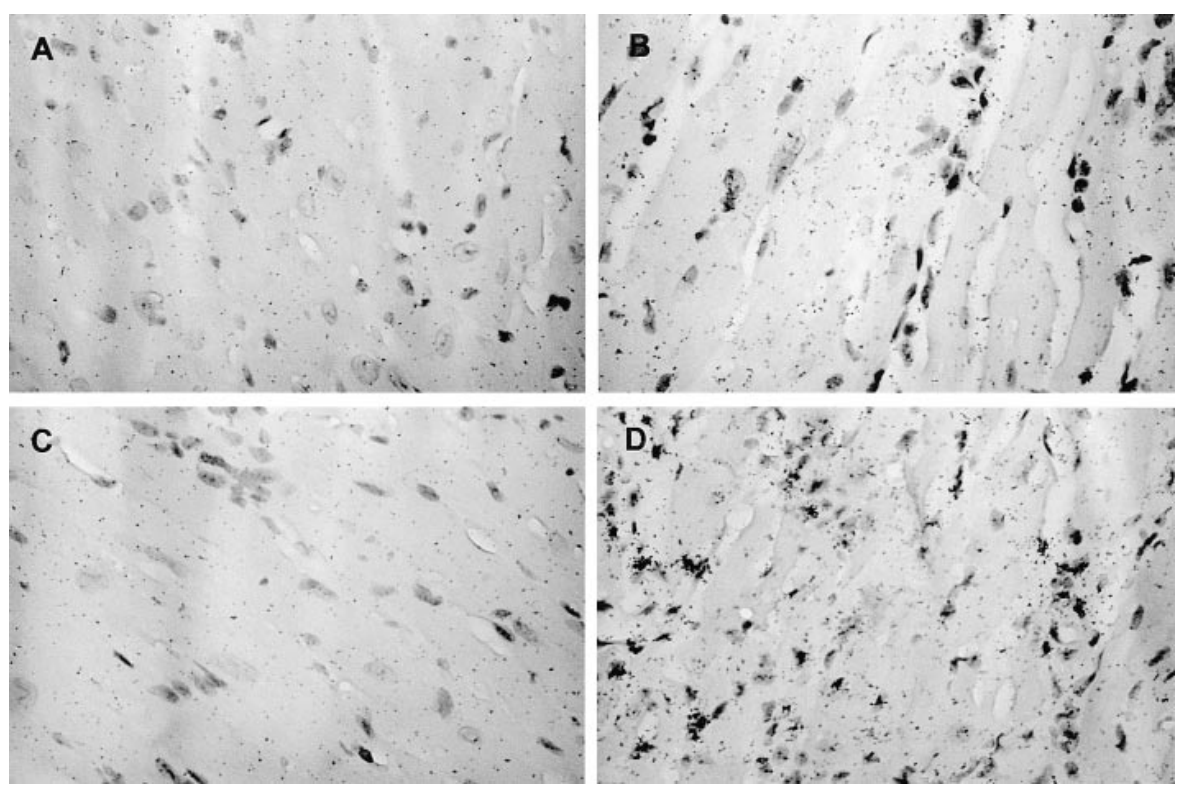

Figure 3. In situ hybridization for positiveand negative-strand viral RNA in the ventricle. Strand-specific in situ hybridization of a nontransgenic littermate $(A$ and $C$ ) and a positive transgenic $(B$ and $D)$ using strand-specific CVB3 RNA probes. The degree of autoradiographic labeling after 3 wk of exposure is clearly above background and consistent with restricted viral replication. The levels of viral positive $(B)$ and viral negative $(D)$ strand RNA correspond with those detected by RT-PCR (Fig. 2). The number of silver grains per $2,000 \mu \mathrm{m}^{2}$ for panels $A-D$ is $47.0 \pm 1.6$, $91.3 \pm 8.9,42.2 \pm 3.0$, and $157 \pm 9.2$, respectively. expected, there is a higher level of positive- than negativestrand viral RNA after infection with wild-type virus (5).

In situ hybridization of the hearts of adult transgenic and nontransgenic mice using strand-specific CVB3 RNA probes as described previously $(5,27)$ confirmed that there was more negative- than positive-strand viral RNA in the ventricles of the transgenic mice (Fig. 3). The viral RNA was dispersed throughout both ventricles and was present at significantly lower levels than that typically observed in the heart during the acute phase of infection with CVB3 (27). The low ratio of positive- to negative-strand RNA observed on in situ hybridization is similar to that observed with RT-PCR amplification of the viral genome from the transgenic ventricles (Fig. 2). Moreover, the presence of both positive- and negative-strand viral RNA indicates that the viral RNA-dependent RNA polymerase $\left(3 \mathrm{D}^{\mathrm{pol}}\right)$ and other viral proteins required for replication of viral RNA are expressed. However, viral protein expression could not be detected by immunoblotting of protein extracts from transgenic hearts, indicating that the level of viral protein expression is below the sensitivity of immunohistochemical techniques.

The decreased ratio of positive- to negative-strand viral RNA and the low level of viral RNA in the transgenic ventricle when compared with the level of RNA in acutely infected mice are reminiscent of the restricted viral replication that was observed in a murine model of ongoing wild-type Coxsackievi- ral infection of the myocardium (5). As expected, infectious virus progeny could not be isolated from the hearts of these transgenic mice, whereas it was readily isolated from the hearts of mice that were infected with wild-type CVB3 (Fig. 4).

Since the MLC-2v gene is expressed as early as day E8.5 of embryonic development, it was anticipated that there would be immune tolerance to the viral proteins. This was confirmed by measuring CVB3 neutralizing antibody in serum from transgenic mice. The neutralizing titer was $<1: 8$ in transgenic mice $(n=4)$ while it was $>1: 640$ in sera known to contain CVB3 neutralizing antibody.

Evidence of cardiomyopathy in transgenic mice. Hearts from transgenic mice had macroscopically normal cardiac anatomy, but in line 53 there was severe left atrial enlargement with large atrial thrombi in two of five atria, and mild left atrial enlargement in line 49 (Fig. 5 and Table I). There was also evidence of myocyte hypertrophy as assessed by cross-sectional cell area (Table I), and an increase in ventricular weight/body weight ratio in the transgenic mice from line 53 , but the increased ventricular weight alone was not statistically significant.

Cardiomyopathy and ventricular hypertrophy are usually associated with an increase in embryonic program of gene expression in the ventricle that includes induction of ANF (28). There was an increase in ANF mRNA as assessed by Northern blotting of RNA from the ventricles of the transgenic mice when compared with nontransgenic littermates (Fig. 6). This upregu-

Table I. Ventricular (Vent) and Left Atrial (LA) Weights with Body Weight (BW) Ratios and Mean Cross-sectional Myocyte Area Measured at the Level of the Nucleus from Transgenic Mice and Nontransgenic Littermates

\begin{tabular}{|c|c|c|c|c|c|}
\hline & Vent weight & LA weight & Vent weight/BW & LA weight/BW & Cell area \\
\hline & $m g$ & $m g$ & $m g / g$ & $m g / g$ & $\mu m^{2}$ \\
\hline Line $49(n=6)$ & $113.5 \pm 7.0$ & $4.8 \pm 1.0$ & $4.6 \pm 0.2$ & $0.19 \pm .02 *$ & $339 \pm 28 *$ \\
\hline Line $53(n=4)$ & $120.6 \pm 4.4$ & $21.3 \pm 8.8^{*}$ & $8.4 \pm 1.1 *$ & $1.76 \pm 0.9^{*}$ & $469 \pm 35^{*}$ \\
\hline Nontransgenics $(n=6)$ & $115.9 \pm 3.8$ & $3.5 \pm 0.9$ & $4.2 \pm 0.3$ & $0.13 \pm 0.01$ & $210 \pm 12$ \\
\hline
\end{tabular}

${ }^{*} P<0.05$ compared to nontransgenic littermates using two-tailed Student's $t$ test. Values shown are mean \pm SE. 

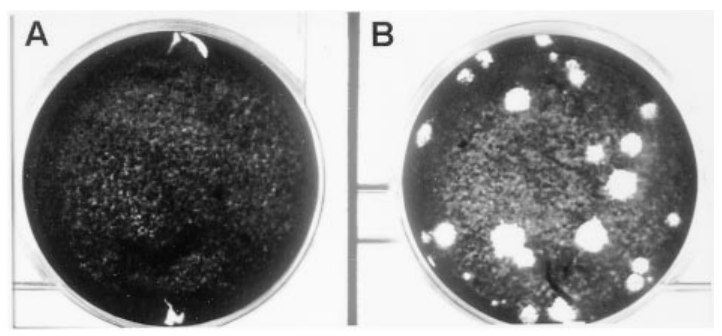

Figure 4. Absence of biologically assayable infectious viral progeny in the ventricles of transgenic mice. The ventricle from either a transgenic mouse $(A)$ or an infected nontransgenic mouse $(B)$ was homogenized and assayed for the presence of infectious viral particles. Whereas infectious viral particles could be easily isolated from the ventricle of the infected wild-type mice $\left(2.1 \times 10^{5} \mathrm{PFU} / 100 \mathrm{mg}\right.$ of tissue), infectious viral particles were not isolated from MLC-2v CVB3 $\Delta$ VP0 transgenic mice.

lation of ANF mRNA is typical of that observed in other models of ventricular hypertrophy and cardiomyopathy (28-30).

Histologic analyses of transverse sections of hearts from transgenic mice and nontransgenic littermates at 1-12 mo of age were stained with hematoxylin and eosin and Masson Trichrome stains. Severe replacement fibrosis was noted in all positive transgenic mice from line 53, whereas mild fibrosis was noted in the hearts of transgenic mice from line 49 (Fig. 7). No significant fibrosis was noted in nontransgenic littermates. The fibrosis in line 53 was present throughout the ventricular wall, but was most prominent in the subendocardial regions. In mice from line 49, fibrosis was scattered throughout the ventricle and the perivascular region. There was not significant cellular infiltrate in the mildly affected hearts that had evidence of cardiomyopathy.

Increased mortality is a feature of some forms of cardiomyopathy. $\mathrm{F}_{1}$ transgenic mice from line 53 had premature mortality becoming severely ill, or dying at 9-12 wk of age (five of five transgene-positive $F_{1}$ mice). The nontransgenic littermates from line 53 lived up to a year and had no evidence of illness. Mice from lines 36 and 49 did not have evidence of increased mortality up to $1 \mathrm{yr}$ of age, and were able to breed with a normal Mendelian distribution of transgene-positive and transgene-negative offspring.

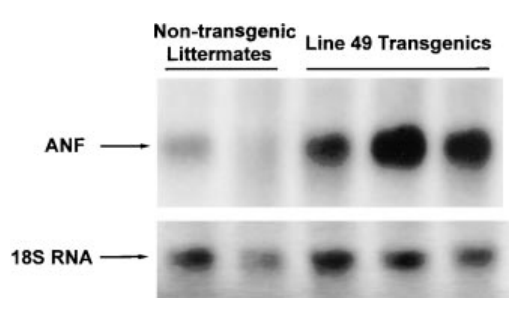

Figure 6. Increase in ventricular ANF mRNA levels. RNA from the ventricles of transgenic and nontransgenic mice were probed by Northern blotting using a rat ANF cDNA probe.

To determine whether there was evidence of a nonspecific systemic illness in positive transgenic mice, a complete blood count from four transgenic mice from line 49 and five nontransgenic littermates was measured using a Baker 9000 hematology analyzer. There was no significant difference in white blood cell count $(10.4 \pm 1.0$ vs. $9.2 \pm 0.8)$, white blood cell differential, or platelet number $(301 \pm 32$ vs. $401 \pm 58)$. There was a small but significant increase in the hemoglobin concentration in the transgenic mice $(15.9 \pm 0.2$ vs. $14.9 \pm 0.2$, transgenic vs. control, $P<0.05)$.

TUNEL staining of adult ventricles demonstrated that there was a similarly low number of apoptotic nuclei in myocytes from transgenic mice from lines 36 and 49 as were present in nontransgenic littermates. The number of TUNEL-positive nuclei in a mid-ventricle cross-section was $3.7 \pm 0.56$ for transgenic mice $(n=6)$ and $5.5 \pm 0.96$ for nontransgenic littermates $(n=4)$. Greater than $50 \%$ of nuclei in sections treated with DNase I were TUNEL positive. This suggests that in the adult animal an increase in the rate of apoptosis at a time that corresponds with the presence of cardiomyopathy in the CVB3 $\Delta$ VP0 transgenic mouse does not account for the ventricular dysfunction. This finding is consistent with recent data that demonstrate that picornaviral-mediated induction of $\mathrm{NFKB}$ can inhibit apoptotic cell death in animals infected with virus (31).

Abnormal ventricular function on echocardiography. To determine whether expression of replication-restricted CVB3 genomes was sufficient to affect cardiac function in vivo, transthoracic M-mode echocardiograms were obtained in closed chest heterozygous transgenic mice from lines 36 and 49. Nontransgenic littermates were analyzed as controls. Chamber dilation in the transgenic mice was manifest by a significant increase in left ventricular end-diastolic dimension and endsystolic dimension. Abnormal systolic performance was evi-

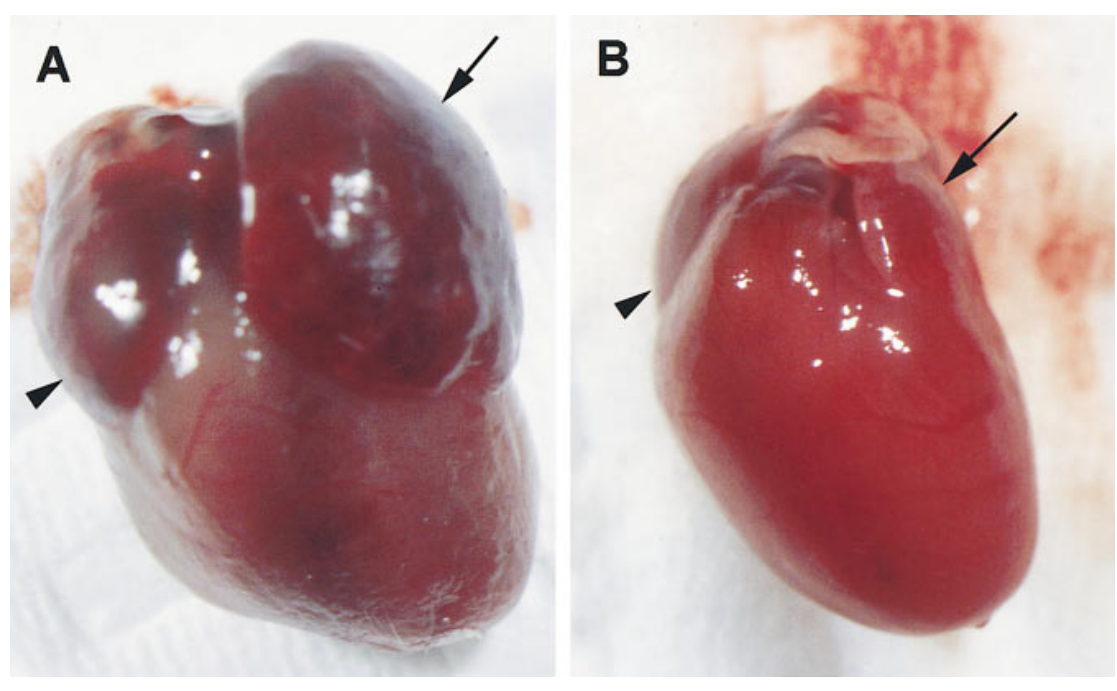

Figure 5. Increased atrial size in transgenic mice. The hearts of a transgenic mouse from line $53(A)$ and a nontransgenic littermate $(B)$ are shown. There is marked enlargement of both the left (arrow) and right (arrowhead) atria of the transgenic mouse. 

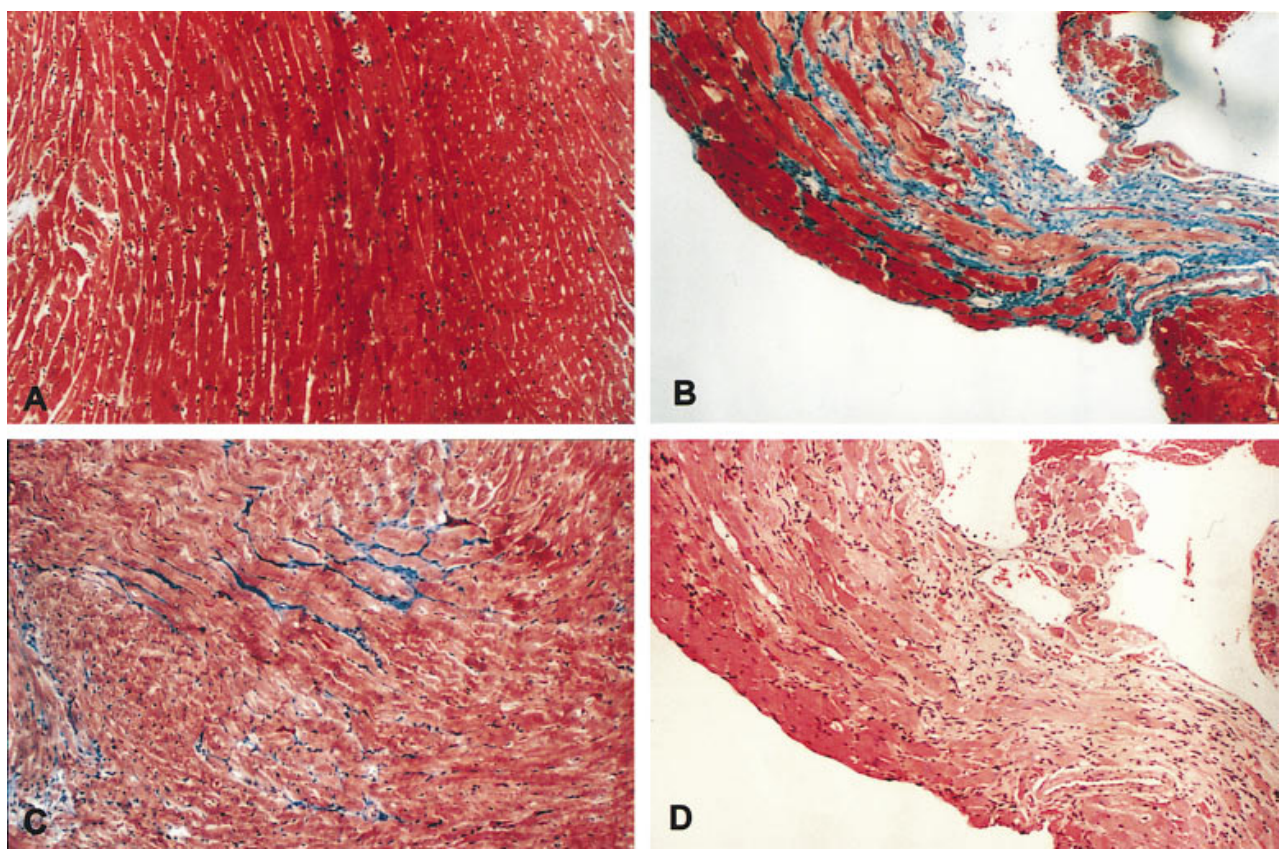

Figure 7. Histologic findings in the ventricles of transgenic mice. Ventricular histology in nontransgenic $(A)$ and transgenic $(B-D)$ mice was analyzed using trichrome stain $(A-C)$ and hematoxylin and eosin stain $(D)$. There is extensive interstitial replacement fibrosis in the ventricles of mice from line 53 ( $B$ and $D$ ) at 4-6 wk of age. There was mild fibrosis in the ventricles of transgenic mice from line 49 (C) at 9 mo of age. denced by a significant decrease in the fractional shortening of the left ventricle (Fig. 8). The average body weight, heart rate, and arterial pressure for the transgenic mice were not significantly different than those of the control mice.
Defective EC coupling and abnormal cell shortening in myocytes isolated from CVB3AVP0 transgenic mice. Previous experiments have demonstrated that a defect in EC coupling can be found in cardiac myocytes taken from animals with pres-
A

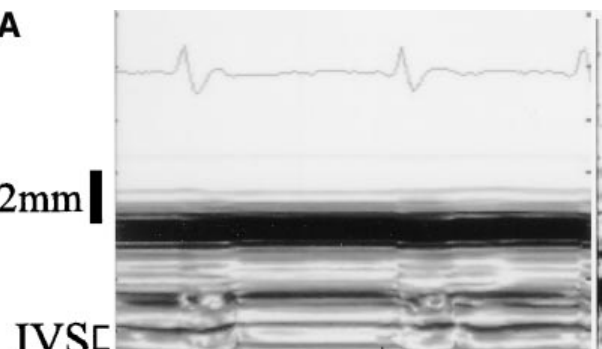

IVSᄃ

PWc

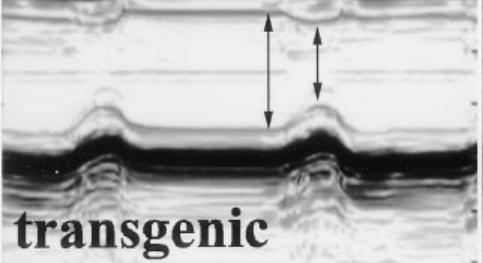

$0.1 \mathrm{~s}$

B

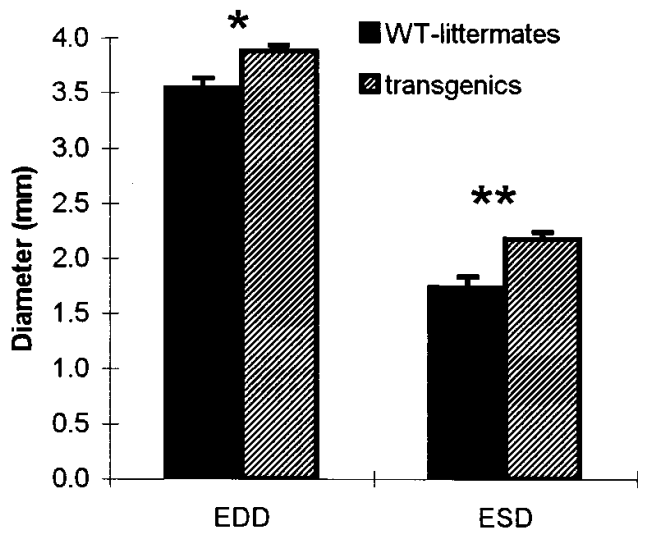

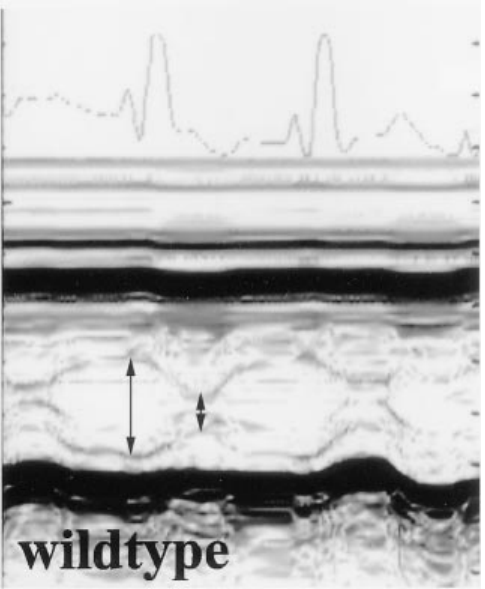

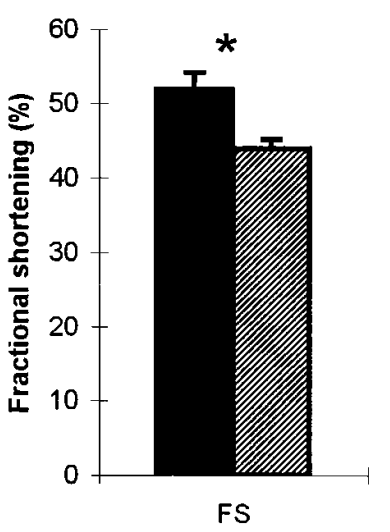

Figure 8. Echocardiographic evidence of cardiomyopathy. $(A)$ Transthoracic M-mode echocardiographic tracings from a CVB $3 \Delta \mathrm{VP} 0$ transgenic mouse from line 49 (left) and a wild-type mouse (right). The interventricular septum (IVS) and posterior wall $(P W)$ of the left ventricle are shown. The double headed vertical arrows indicate the left ventricular chamber dimension at end diastole (longer arrow) and at end systole (shorter arrow). The left ventricle is dilated in the transgenic mouse and there is reduced wall motion, demonstrating the decrease in left ventricle systolic function. The heart rate in the transgenic mouse shown is slightly slower than that of the wild-type mouse shown, but the average heart rates of the two groups were not significantly different. (B) Transthoracic M-mode echocardiographic measurements from nontransgenic littermates (WT-littermates) and transgenic mice from lines 36 and 49 (transgenics) are shown. There is a significant increase in end-diastolic dimension $(E D D)$ and end-systolic dimension $(E S D)$ in the transgenic mice. The fractional shortening $(F S)$ is lower in the transgenic mice. Results represent mean \pm SE of 14 wild-type littermates and 45 transgenic mice. $* P<0.05, * * P<0.01$. 

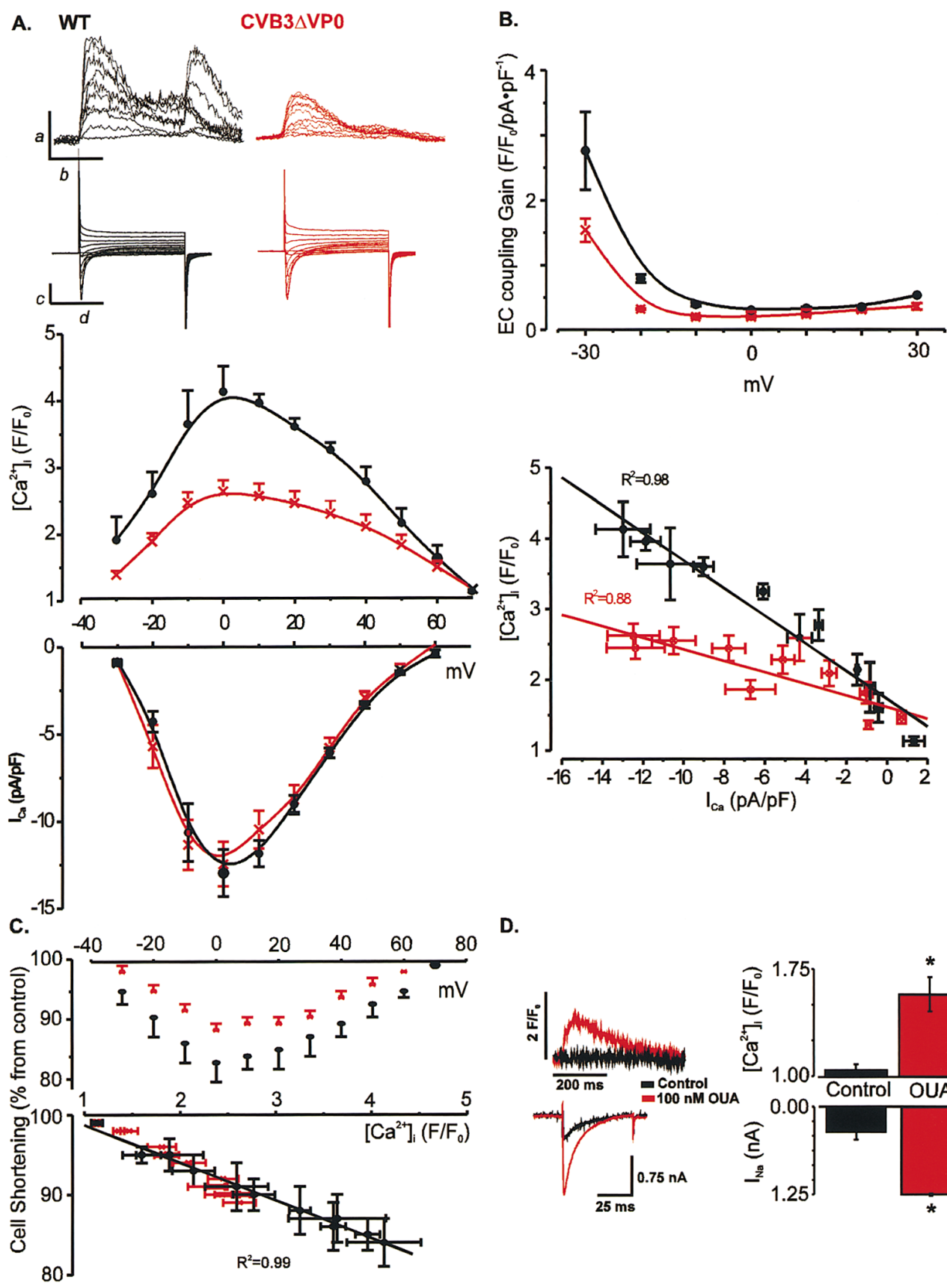

Figure 9. EC coupling in wildtype and CVB3 3 VP0 mouse ventricular myocytes. $(A, t o p)$ $\left[\mathrm{Ca}^{2+}\right]_{\mathrm{i}}$ transients and $\mathrm{I}_{\mathrm{Ca}}$ from wild-type (black lines) and CVB3 3 VP0 (red lines) ventricular myocytes. Depolarizations of $200 \mathrm{~ms}$ duration were applied to test potentials $(-30$ to $+70 \mathrm{mV})$ from the holding potential of $-40 \mathrm{mV}$. During these experiments $\mathrm{I}_{\mathrm{Ca}}$ and $\left[\mathrm{Ca}^{2+}\right]_{\mathrm{i}}$ were recorded simultaneously. Scale bars labeled $a-d$ represent 2.5 $\mathrm{F} / \mathrm{F}_{0}, 100 \mathrm{~ms}, 1 \mathrm{nA}$, and $100 \mathrm{~ms}$, respectively. (Middle) The peak amplitude of the cell-wide $\left[\mathrm{Ca}^{2+}\right]_{\mathrm{i}}$ transient is plotted as a function of voltage in wildtype (black circles; $n=6$ ) and CVB3 3 VP0 cells $($ red crosses; $n=$ 4). (Bottom) $\mathrm{I}_{\mathrm{Ca}}$ is plotted as a function of voltage. (B) EC coupling gain function: $\Delta\left[\mathrm{Ca}^{2+}\right]_{i} / \mathrm{I}_{\mathrm{Ca}}$ is plotted against membrane potential in wild-type and CVB3 4 VP0 cells (top). The amplitude of the $\left[\mathrm{Ca}^{2+}\right]_{i}$ transient is plotted against $\mathrm{I}_{\mathrm{Ca}}$ for wild-type and CVB3 $\Delta$ VP0 ventricular myocytes. The data in this figure were fitted (straight lines) with a linear regression equation using a least-squares routine [wildtype, $R^{2}=0.98$, slope $=-0.196$ $\mathrm{F} / \mathrm{F}_{0}\left(\mathrm{pA} \cdot \mathrm{pF}^{-1}\right)^{-1} ; \mathrm{CVB} 3 \Delta \mathrm{VP} 0$,

D.

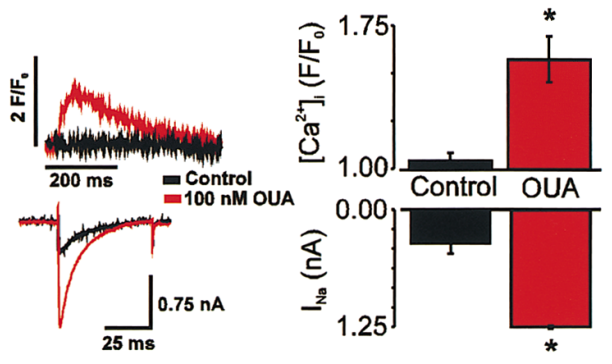
$R^{2}=0.88$, slope $=-0.082 \mathrm{~F} / \mathrm{F}_{0}$ $\left.\left(\mathrm{pA} \cdot \mathrm{pF}^{-1}\right)^{-1}\right] .(C)$ Contraction, measured as cell shortening, plotted as a function of voltage (top) and as a function of $\left[\mathrm{Ca}^{2+}\right]_{\mathrm{i}}$ (bottom) illustrates the voltage dependence of cell shortening in wild-type and CVB3 3 VP0 cells. Shown below, in panel $C$, is the magnitude of cell shortening as a function of the peak amplitude of the cell-wide $\left[\mathrm{Ca}^{2+}\right]_{\mathrm{i}}$ transient $(n=6)$. Wild-type and CVB3$\triangle \mathrm{VP} 0$ data could be fitted $(P>$ 0.05 ) with a single regression equation $(P<0.05)$ with regression coefficient $\left(R^{2}\right)$ of 0.99 and a slope of $-0.047 \mathrm{~F} / \mathrm{F}_{0}$ (percent cell shortening) ${ }^{-1}$. $(D)$ Activation of slip-mode conductance (25). ( Left) $\left[\mathrm{Ca}^{2+}\right]_{\mathrm{i}}$ and $\mathrm{I}_{\mathrm{Na}}$ records obtained from a representative CVB3 $\Delta \mathrm{VP0}$ cell during a 50-ms step depolarization from the holding potential of $-90 \mathrm{mV}$ to $-65 \mathrm{mV}$ under control conditions (black lines) and after the application of $100 \mathrm{nM}$ ouabain (red lines). (Right) The bar graphs in the right portion of this panel plot the mean $( \pm \mathrm{SE})$ values of the amplitude of the $\left[\mathrm{Ca}^{2+}\right]_{\mathrm{i}}$ transient $($ top $)$ and $\mathrm{I}_{\mathrm{Na}}($ bottom $)$ that were recorded under control conditions (black) and while CVB3 $\Delta$ VP0 cells $(n=4)$ were bathed with a solution containing $100 \mathrm{nM}$ ouabain $($ red; $* P<0.05)$.

sure-overload cardiac hypertrophy or failure (17). However, it is not known if cardiomyopathy that occurs from widely disparate etiologies is associated with a similar abnormality in EC coupling as that previously reported in SH-HF rats in heart failure (17). Surprisingly, single myocytes obtained from the same CVB3 $\triangle$ VP0 transgenic lines that had cardiomyopathy based on echocardiogram also had abnormal EC coupling. The $\left[\mathrm{Ca}^{2+}\right]_{\mathrm{i}}$ transients were decreased compared with age-matched nontransgenic littermates (Fig. $9 A$, top). In average data obtained from transgenic and control myocytes the amplitude of $\left[\mathrm{Ca}^{2+}\right]_{\mathrm{i}}$ transient (shown as $\mathrm{F} / \mathrm{F}_{0}$ ) was reduced (Fig. $9 \mathrm{~A}$, middle), whereas the $\mathrm{I}_{\mathrm{Ca}}$ current density was unaltered (Fig. $9 A$, bottom).

Fig. $9 B$ (top) shows that the EC coupling gain function $\left(\Delta\left[\mathrm{Ca}^{2+}\right]_{\mathrm{i}} / \mathrm{I}_{\mathrm{Ca}}\right.$ vs. voltage $)$ is decreased in transgenic mice compared with nontransgenic littermates. This function estimates 
how the $\left[\mathrm{Ca}^{2+}\right]_{\mathrm{i}}$ transient per $\mathrm{I}_{\mathrm{Ca}}$ changes at different voltages (32). The dependence of the $\left[\mathrm{Ca}^{2+}\right]_{\mathrm{i}}$ transient on $\mathrm{I}_{\mathrm{Ca}}$ is plotted in Fig. $9 B$ (bottom). Fig. $9 C$ (top) shows the decrease in voltage-dependent cell shortening of wild-type and transgenic myocytes. However, the magnitude of cell shortening as a function of the peak amplitude of the cell-wide $\left[\mathrm{Ca}^{2+}\right]_{\mathrm{i}}$ transient is not different between wild-type and transgenic myocytes (Fig. $9 C$, bottom). This suggests that the contractile proteins are working normally. The recently described slip-mode conductance of the cardiac $\mathrm{Na}^{+}$channels was preserved in the transgenic mice (Fig. $9 \mathrm{D}$ ), thereby providing an additional therapeutic pathway to treat the cardiomyopathy.

These findings suggest that the abnormalities in cardiac function that are observed on echocardiography by expression of CVB3 3 VP0 genomes in the heart may be caused by a cellular defect in EC coupling. This defect contributes to the decrease in contractile function just as it does in heart failure associated with pressure overload. In the case of CVB3 induced cardiomyopathy cardiotonic steroids (e.g., digoxin or ouabain) can increase the $\left[\mathrm{Ca}^{2+}\right]_{\mathrm{i}}$ transient by activating $\mathrm{Ca}^{2+}$ flux through $\mathrm{Na}^{+}$channels.

\section{Discussion}

A main conclusion from this study is that cardiac expression of replication-restricted Coxsackieviral genomes is sufficient to induce dilated cardiomyopathy in the intact heart, demonstrating that there can be a direct cause-effect relationship between the presence of the enteroviral genomes and cardiomyopathy. In addition to the previously identified role of enteroviruses in acute myocarditis, these experiments provide evidence that replication of enteroviral genomes in the heart can be pathogenetic by interfering with myocyte function, and thus have a role in the pathogenesis of dilated cardiomyopathy. The study also demonstrates that one of the mechanisms associated with abnormal myocyte function in this model is defective EC coupling. These findings contribute to our understanding of the pathogenesis of some forms of dilated cardiomyopathy in humans, evolving from persistent heart muscle infection.

Hallmarks of dilated cardiomyopathy in humans include a decrease in systolic ventricular function and an increase in ventricular chamber size. Microscopic features include variable degrees of interstitial fibrosis, degeneration of myocytes, and occasional clusters of lymphocytes (33). A molecular marker of ventricular hypertrophy and cardiomyopathy is the induction of an embryonic program of gene expression that includes expression of ANF in the ventricle. These characteristics are consistent in human and animal models of cardiomyopathy. Since the major objective of this study was to determine whether restricted replication of enteroviral genomes in the heart could induce cardiomyopathy, we sought to determine whether some or all of the characteristics of cardiomyopathy were present in the transgenic mice. Echocardiographic data demonstrated an increase in left ventricular end-diastolic and end-systolic chamber size in transgenic mice that was associated with decreased fractional shortening, a marker of systolic dysfunction. Histologic analysis of the transgenic mice demonstrated variable degrees of fibrosis and degeneration of myocytes. The most severely affected mice from line 53 had severe interstitial fibrosis throughout the ventricle. There was no detectable CVB3 neutralizing antibody in the sera of transgenic mice, thus confirming our hypothesis that early embryonic ex- pression of the viral transgene directed by the MLC-2v promoter (34) would be associated with immune tolerance toward the viral proteins. This characteristic is clearly distinct from the potent immune response associated with acute viral infection. The mechanisms by which transgenic expression of the CVB3$\triangle \mathrm{VP} 0$ transgene induces cardiomyopathy are undergoing further investigation particularly with regard to the pathobiology of viral proteinases.

In addition to decreased function and histologic abnormalities, other manifestations of cardiomyopathy in the transgenic mice included the induction of ventricular ANF gene expression, left atrial enlargement, and in one line, an increase in mortality. Ventricular expression of ANF is a relatively consistent marker in human and animal models of cardiomyopathy and ventricular hypertrophy, regardless of the specific etiology (28). The increase of left atrial size and the presence of atrial thrombi that was observed in CVB3 $3 \mathrm{VP} 0$ transgenic mice are consistent with previously published transgenic models of ventricular hypertrophy $(21,35)$. It is presumed that the increased left atrial size results from abnormal left ventricular filling pressures that cause secondary dilation of the left atrium.

Another hallmark of dilated cardiomyopathy in humans is an increase in mortality. In our experiments only mice from line 53 that had severe cardiomyopathy had early mortality. Even though it is clear that the early mortality in transgenic mice from line 53 is associated with severe cardiomyopathy, the precise cause of cardiac death in these animals remains to be elucidated. The nontransgenic littermates did not die prematurely, and transgenic mice from other founder lines that had normal life expectancy and bred well seemed to have a milder form of cardiomyopathy.

Previously, other transgenic models have provided insight into the pathogenesis of myocardial hypertrophy. Myocardial expression of a constitutively active $\mathrm{H}$-Ras under the direction of the 250-bp MLC-2v promoter induced hypertrophic cardiomyopathy, implicating Ras in obstructive hypertrophy in the intact heart $(21,36)$. It also has been shown that mutation of myosin heavy chain at an amino acid that is mutated in some forms of human hypertrophic cardiomyopathy can cause hypertrophic cardiomyopathy in mice which exhibit characteristics similar to those observed in human hypertrophic cardiomyopathy (35). Transgenic mice may also be valuable in defining potential mechanisms associated with dilated cardiomyopathy. Knockout of the muscle LIM protein has been shown to cause a severe cardiomyopathy (37), and it seems likely that disruption of other cytoskeletal proteins may also be involved in cardiomyopathy. Transgenic mice that have cardiomyopathy as a result of such "loss of function" mutations will be valuable in studying the effects that occur secondary to cardiomyopathy. However, the cardiomyopathy in this study results from transgenic expression of viral genomes that have been associated with acute myocarditis and dilated cardiomyopathy. This approach may improve our understanding of the mechanisms that initiate ventricular dysfunction as well as contribute to its progression.

Abnormalities in EC coupling have been shown to occur in cardiomyopathy associated with pressure overload (17). However, it is not known if cardiomyopathy of divergent etiologies have similar alterations in EC coupling. The data from myocytes isolated from the CVB3 3 VPO transgenic mice show for the first time that a cardiomyopathy that occurs by mechanisms that are independent of pressure overload also has ab- 
normal EC coupling and decreased magnitude of cell shortening. These results reinforce the echocardiographic data and suggest that there are conserved mechanisms by which distinct causes of cardiomyopathy can cause abnormal ventricular function.

Expression of viral genomes in transgenic mice has contributed to the understanding of the pathogenesis of disease associated with several viruses. For example, expression of the hepatitis B virus large envelope polypeptide clearly defined a role for hepatitis B virus proteins in the pathogenesis of hepatocellular carcinoma (38). Expression of human immunodeficiency virus has demonstrated a role for HIV genome in progressive glomerulosclerosis (39), an AIDS-like cachexia syndrome (40), and neurologic disease (41). The experiments discussed in this manuscript are the first that describe transgenic expression of a picornaviral genome, and the first that describe the induction of cardiomyopathy from expression of viral genomes.

The molecular mechanisms by which restricted enteroviral replication in the heart can induce dilated cardiomyopathy are currently under investigation. Data obtained in other cell types, and recently in cardiac myocytes (Wessely, R., and K.U. Knowlton, unpublished observation), have demonstrated that picornaviral proteinases have a significant effect on host cell translation and transcriptional mechanisms. The Coxsackieviral proteinase $2 \mathrm{~A}\left(2 \mathrm{~A}^{\mathrm{pro}}\right)$ is not only important for cleavage of the viral polyprotein, but is associated with cleavage of the host cell eukaryotic initiation factor-4G (eIF4G) $(42,43)$. The eukaryotic initiation factor complex has a key role in the initiation of cap-dependent translation of eukaryotic mRNA (42, $43)$. Similarly, the viral proteinase $3 \mathrm{C}\left(3 \mathrm{C}^{\text {pro }}\right)$ has been shown to cleave the host cell transcription binding protein that is involved in initiation of TATA-dependent transcription $(44,45)$. Thus, it is possible that restricted virus replication is sufficient to induce a direct cytotoxic effect on cardiac myocytes by inhibiting host cell transcriptional and/or translational mechanisms. In addition, the presence of double-stranded viral RNA of the replicative viral intermediate may activate intracellular signaling mechanisms such as NFKB or double-stranded RNAdependent protein kinase (PKR) that may influence viral pathogenesis (46-48).

The role of viral infection in heart disease has been difficult to define for a number of reasons, including lack of genetic animal models with relevance to human disease. To better define the mechanisms by which viruses can cause dilated cardiomyopathy, we have generated transgenic mice to demonstrate that cardiac expression of mutant Coxsackieviral genomes is sufficient to induce cardiomyopathy without formation of infectious viral progeny. Future experiments will allow dissection of specific viral gene regions that interfere with myocyte function, e.g., viral proteinases, in both acute and chronic disease. Transgenic models of cardiomyopathy, such as that described above, with etiologic relevance to the pathogenesis of human cardiomyopathy will be valuable to identify new therapeutic strategies for treatment and prevention of dilated cardiomyopathy in humans.

\section{Acknowledgments}

We wish to thank Kenneth R. Chien for his advice and support pertaining to these experiments, and John Ross, Jr. for reviewing the manuscript and valuable advice and resources to complete the echocardiographic studies.
This work represents equal contributions from the laboratories of R. Kandolf and K.U. Knowlton and was supported by grants from the National Institutes of Health (HL-02618) to K.U. Knowlton, the American Heart Association (AHA CA-94-276) to K.U. Knowlton, Deutsche Forschungsgemeinschaft (We 1811-1) to R. Wessely, the German Ministry for Education and Research and the Interdisciplinary Clinical Research Center (IKFZ) Tübingen, Germany to R. Kandolf, and National Institutes of Health (HL-36974, HL-25675) to W.J. Lederer.

\section{References}

1. Martino, T.A., P. Liu, and M.J. Sole. 1994. Viral infection and the pathogenesis of dilated cardiomyopathy. Circ. Res. 74:182-188.

2. Kandolf, R., K. Klingel, R. Zell, H.C. Selinka, U. Raab, W. SchneiderBrachert, and B. Bultmann. 1993. Molecular pathogenesis of enterovirusinduced myocarditis: virus persistence and chronic inflammation. Intervirology. 35:140-151.

3. Hosenpud, J.D., R.J. Novick, L.E. Bennett, B.M. Keck, B. Fiol, and O.P. Daily. 1996. The Registry of the International Society for Heart and Lung Transplantation: thirteenth official report-1996. J. Heart Lung Transplant. 15: 655-674.

4. McManus, B.M., and R. Kandolf. 1991. Evolving concepts of cause, consequence, and control in myocarditis. Curr. Opin. Cardiol. 6:418-427.

5. Klingel, K., C. Hohenadl, A. Canu, M. Albrecht, M. Seemann, G. Mall, and R. Kandolf. 1992. Ongoing enterovirus-induced myocarditis is associated with persistent heart muscle infection: quantitative analysis of virus replication, tissue damage, and inflammation. Proc. Natl. Acad. Sci. USA. 89:314-318.

6. Borzakian, S., T. Couderc, Y. Barbier, G. Attal, I. Pelletier, and F. Colbere-Garapin. 1992. Persistent poliovirus infection: establishment and maintenance involve distinct mechanisms. Virology. 186:398-408.

7. Brahic, M., W.G. Stroop, and J.R. Baringer. 1981. Theiler's virus persists in glial cells during demyelinating disease. Cell. 26:123-128.

8. Carp, R.I. 1981. Persistent infection of human lymphoid cells with poliovirus and development of temperature-sensitive mutants. Intervirology. 15:4956.

9. Colbere-Garapin, F., C. Christodoulou, R. Crainic, and I. Pelletier. 1989. Persistent poliovirus infection of human neuroblastoma cells. Proc. Natl. Acad. Sci. USA. 86:7590-7594.

10. de la Torre, J.C., M. Davila, F. Sobrino, J. Ortin, and E. Domingo. 1985. Establishment of cell lines persistently infected with foot-and-mouth disease virus. Virology. 145:24-35.

11. Sharief, M.K., R. Hentges, and M. Ciardi. 1991. Intrathecal immune response in patients with the post-polio syndrome. N. Engl. J. Med. 325:749-755.

12. Kandolf, R., A. Canu, and P.H. Hofschneider. 1985. Coxsackie B3 virus can replicate in cultured human foetal heart cells and is inhibited by interferon. J. Mol. Cell Cardiol. 17:167-181.

13. Matteucci, D., M. Paglianti, A.M. Giangregorio, M.R. Capobianchi, F. Dianzani, and M. Bendinelli. 1985. Group B Coxsackieviruses readily establish persistent infections in human lymphoid cell lines. J. Virol. 56:651-654.

14. Cao, Y., and D.P. Schnurr. 1988. Persistent infection of YAC-1 cells by Coxsackievirus B3. J. Gen. Virol. 69:59-65.

15. Wessely, R., A. Henke, R. Zell, R. Kandolf, and K.U. Knowlton. 1998. Low level expression of a mutant Coxsackieviral cDNA induces a myocytopathic effect in culture: an approach to the study of enteroviral persistence in cardiac myocytes. Circulation. 98:450-457.

16. Lee, K.J., R.S. Ross, H.A. Rockman, A.N. Harris, T.X. O'Brien, M. Van Bilsen, H.E. Shubeita, R. Kandolf, G. Brem, and J. Price. 1992. Myosin light chain-2 luciferase transgenic mice reveal distinct regulatory programs for cardiac and skeletal muscle-specific expression of a single contractile protein gene. J. Biol. Chem. 267:15875-15885.

17. Gomez, A.M., H.H. Valdivia, H. Cheng, M.R. Lederer, L.F. Santana, M.B. Cannell, S.A. McCune, R.A. Altschuld, and W.J. Lederer. 1997. Defective excitation-contraction coupling in experimental cardiac hypertrophy and heart failure. Science. 276:800-806.

18. Kandolf, R., and P.H. Hofschneider. 1985. Molecular cloning of the genome of a cardiotropic Coxsackie B3 virus: full-length reverse-transcribed recombinant cDNA generates infectious virus in mammalian cells. Proc. Natl. Acad. Sci. USA. 82:4818-4822.

19. Klump, W.M., I. Bergmann, B.C. Muller, D. Ameis, and R. Kandolf. 1990. Complete nucleotide sequence of infectious Coxsackievirus B3 cDNA: two initial $5^{\prime}$ uridine residues are regained during plus-strand RNA synthesis. $J$. Virol. 64:1573-1583.

20. Sambrook, J., E.F. Fritsch, and T. Maniatis. 1989. Molecular Cloning: A Laboratory Manual. Cold Spring Harbor Laboratory, Cold Spring Harbor, NY. 21. Hunter, J.J., N. Tanaka, H.A. Rockman, J. Ross, Jr., and K.R. Chien. 1995. Ventricular expression of a MLC-2v Ras fusion gene induces cardiac hypertrophy and selective diastolic dysfunction in transgenic mice. J. Biol. Chem. 270:23173-23178. 
22. Hohenadl, C., K. Klingel, J. Mertsching, P.H. Hofschneider, and R. Kandolf. 1991. Strand-specific detection of enteroviral RNA in myocardial tissue by in situ hybridization. Mol. Cell Probes. 5:11-20.

23. Tanaka, N., N. Dalton, L. Mao, H.A. Rockman, K.R. Gottshall, J. Hunter, K.R. Chien, and J. Ross, Jr. 1996. Transthoracic echocardiography in models of cardiac disease in the mouse. Circulation. 94:1109-1117.

24. Santana, L.F., E.G. Kranias, and W.J. Lederer. 1997. Calcium sparks and excitation-contraction coupling in phospholamban-deficient mouse ventricular myocytes. J. Physiol. 503:21-29.

25. Santana, L.F., A.M. Gomez, and W.J. Lederer. 1998. $\mathrm{Ca}^{2+}$ flux through promiscuous cardiac $\mathrm{Na}^{+}$channels: slip-mode conductance. Science. 279:10271033.

26. Hogan, B., F. Constantini, and E. Lacy. 1986. Manipulating the Mouse Embryo: A Laboratory Manual. Cold Spring Harbor Laboratory, Cold Spring Harbor, NY.

27. Kandolf, R., D. Ameis, P. Kirschner, A. Canu, and P.H. Hofschneider. 1987. In situ detection of enteroviral genomes in myocardial cells by nucleic acid hybridization: an approach to the diagnosis of viral heart disease. Proc. Natl. Acad. Sci. USA. 84:6272-6276.

28. Chien, K.R., K.U. Knowlton, H. Zhu, and S. Chien. 1991. Regulation of cardiac gene expression during myocardial growth and hypertrophy: molecular studies of an adaptive physiologic response. FASEB (Fed. Am. Soc. Exp. Biol.) J. 5:3037-3046.

29. Chien, K.R., H. Zhu, K.U. Knowlton, W. Miller-Hance, M. van-Bilsen, T.X. O'Brien, and S.M. Evans. 1993. Transcriptional regulation during cardiac growth and development. Annu. Rev. Physiol. 55:77-95.

30. Parker, T.G., and M.D. Schneider. 1991. Growth factors, proto-oncogenes, and plasticity of the cardiac phenotype. Annu. Rev. Physiol. 53:179-200.

31. Schwarz, E.M., C. Badorff, T.S. Hiura, R. Wessely, A. Badorff, I.M. Verma, and K.U. Knowlton. 1998. NF-kappa B-mediated inhibition of apoptosis is required for encephalomyocarditis virus virulence: a mechanism of resistance in p50 knockout mice. J. Virol. 72:5654-5660.

32. Santana, L.F., H. Cheng, A.M. Gomez, M.B. Cannell, and W.J. Lederer. 1996. Relation between the sarcolemmal $\mathrm{Ca}^{2+}$ current and $\mathrm{Ca}^{2+}$ sparks and local control theories for cardiac excitation-contraction coupling. Circ. Res. 78: $166-171$.

33. Tazelaar, H.D., and M.E. Billingham. 1986. Leukocyte infiltrates in idiopathic dilated cardiomyopathy: a source of confusion with active myocarditis. Am. J. Surg. Pathol. 10:405-412.

34. O'Brien, T.X., K.J. Lee, and K.R. Chien. 1993. Positional specification of ventricular myosin light chain 2 expression in the primitive murine heart tube. Proc. Natl. Acad. Sci. USA. 90:5157-5161.

35. Geisterfer-Lowrance, A.A., M. Christe, D.A. Conner, J.S. Ingwall, F.J. Schoen, C.E. Seidman, and J.G. Seidman. 1996. A mouse model of familial hypertrophic cardiomyopathy. Science. 272:731-734.

36. Gottshall, K.R., J.J. Hunter, N. Tanaka, N. Dalton, K.D. Becker, J. Ross, Jr., and K.R. Chien. 1997. Ras-dependent pathways induce obstructive hypertrophy in echo-selected transgenic mice. Proc. Natl. Acad. Sci. USA. 94: 4710-4715.

37. Arber, S., J.J. Hunter, J. Ross, Jr., M. Hongo, G. Sansig, J. Borg, J.C. Perriard, K.R. Chien, and P. Caroni. 1997. MLP-deficient mice exhibit a disruption of cardiac cytoarchitectural organization, dilated cardiomyopathy, and heart failure. Cell. 88:393-403.

38. Chisari, F.V., K. Klopchin, T. Moriyama, C. Pasquinelli, H.A. Dunsford, S. Sell, C.A. Pinkert, R.L. Brinster, and R.D. Palmiter. 1989. Molecular pathogenesis of hepatocellular carcinoma in hepatitis B virus transgenic mice. Cell. 59:1145-1156.

39. Kopp, J.B., M.E. Klotman, S.H. Adler, L.A. Bruggeman, P. Dickie, N.J. Marinos, M. Eckhaus, J.L. Bryant, A.L. Notkins, and P.E. Klotman. 1992. Progressive glomerulosclerosis and enhanced renal accumulation of basement membrane components in mice transgenic for human immunodeficiency virus type 1 genes. Proc. Natl. Acad. Sci. USA. 89:1577-1581.

40. Santoro, T.J., J.L. Bryant, J. Pellicoro, M.E. Klotman, J.B. Kopp, L.A. Bruggeman, R.R. Franks, A.L. Notkins, and P.E. Klotman. 1994. Growth failure and AIDS-like cachexia syndrome in HIV-1 transgenic mice. Virology. 201: $147-151$.

41. Thomas, F.P., C. Chalk, R. Lalonde, Y. Robitaille, and P. Jolicoeur. 1994. Expression of human immunodeficiency virus type 1 in the nervous system of transgenic mice leads to neurological disease. J. Virol. 68:7099-7107.

42. Lamphear, B.J., R. Yan, F. Yang, D. Waters, H.D. Liebig, H. Klump, E. Kuechler, T. Skern, and R.E. Rhoads. 1993. Mapping the cleavage site in protein synthesis initiation factor eIF-4 gamma of the 2A proteases from human Coxsackievirus and rhinovirus. J. Biol. Chem. 268:19200-19203.

43. Lamphear, B.J., R. Kirchweger, T. Skern, and R.E. Rhoads. 1995. Mapping of functional domains in eukaryotic protein synthesis initiation factor 4G (eIF4G) with picornaviral proteases. Implications for cap-dependent and capindependent translational initiation. J. Biol. Chem. 270:21975-21983.

44. Clark, M.E., P.M. Lieberman, A.J. Berk, and A. Dasgupta. 1993. Direct cleavage of human TATA-binding protein by poliovirus protease $3 \mathrm{C}$ in vivo and in vitro. Mol. Cell Biol. 13:1232-1237.

45. Yalamanchili, P., K. Harris, E. Wimmer, and A. Dasgupta. 1996. Inhibition of basal transcription by poliovirus: a virus-encoded protease (3Cpro) in hibits formation of TBP-TATA box complex in vitro. J. Virol. 70:2922-2929.

46. Sha, W.C., H.C. Liou, E.I. Tuomanen, and D. Baltimore. 1995. Targeted disruption of the p50 subunit of NF-kappa B leads to multifocal defects in immune responses. Cell. 80:321-330.

47. Zhu, Z., W. Tang, A. Ray, Y. Wu, O. Einarsson, M.L. Landry, J. Gwaltney, Jr., and J.A. Elias. 1996. Rhinovirus stimulation of interleukin-6 in vivo and in vitro. Evidence for nuclear factor kappa B-dependent transcriptional activation. J. Clin. Invest. 97:421-430.

48. Yang, Y.L., L.F. Reis, J. Pavlovic, A. Aguzzi, R. Schafer, A. Kumar, B.R. Williams, M. Aguet, and C. Weissmann. 1995. Deficient signaling in mice devoid of double-stranded RNA-dependent protein kinase. EMBO (Eur. Mol. Biol. Organ.) J. 14:6095-6106. 